\title{
Pelatihan Kewirausahaan Pembuatan Izin Usaha Melalui Sistem Online Single Submission (OSS) Bagi UMKM di Sumatera-Selatan
}

\author{
Angga Wibowo Gultom
}

Program Studi Manajemen, Fakultas Ekonomi dan Bisnis, Universitas Baturaja

Email : mr.angga.gultom@gmail.com

Article History:
Received: November
Revised: November
Accepted: November
Available online : Desember

Kata Kunci:

Izin Usaha, Kewirausahaan, Online, $U M K M$

\begin{abstract}
Abstrak:
Legalitas merupakan hal yang sangat penting bagi UMKM untuk mendapatkan pengakuan serta menjadi syarat utama dalam mengakses bantuan pemerintah. Pada masa covid-19 saat ini terdapat bantuan produktif bagi usaha mikro, sayangnya banyak sekali UMKM yang belum memiliki legalitas usaha, sehingga tidak bisa mengakses bantuan tersebut, padahal untuk membuat perizinan usaha bagi UMKM sangatlah mudah, karena dapat dilakukan secara online. Pelatihan kewirausahaan ini diadakan dengan tujuan agar para UMKM memahami dan mengerti untuk membuat izin usaha secara online melalui sistem online single submission (OSS). Metode yang digunakan dalam kegiatan ini ialah sosialisasi, diskusi, serta praktek. Output dari kegiatan pengabdian ini adalah izin usaha online bagi seluruh UMKM peserta kegiatan. Hasil dari pengabdian ini menunjukan bahwa mayoritas UMKM peserta pelatihan $(73,33 \%)$ belum memiliki legalitas usaha, namun setelah mengikuti pelatihan, seluruh peserta (100\%) sudah memiliki legalitas usaha. Berdasarkan hasil tersebut, maka dapat disimpulkan bahwa pelatihan kewirausahaan ini telah berhasil memberikan pemahaman tentang cara pembuatan legalitas usaha secara online bagi seluruh peserta pelatihan.
\end{abstract}




\section{Pendahuluan}

Pada Tahun 2017, tercatat bahwa 60,34\% kontribusi produk domestik bruto (PDB) di Indonesia disumbang oleh Usaha Mikro Kecil (UMK), sedangkan untuk tahun 2018 tercatat bahwa UMKM di Indonesia menyerap 116,9 juta tenaga kerja atau berarti $97 \%$ total tenaga kerja di Indonesia diserap oleh sektor UMKM. Hal ini membuktikan bahwa UMKM sangat efektif dalam mengurangi jumlah pengangguran di Indonesia (Thaha, 2020). Untuk itu sangat penting bagi pemerintah mendukung UMKM untuk terus maju dan berkembang.

Di era digital saat ini, bentuk UMKM tidak terbatas pada toko secara fisik (offline) saja, tetapi para pelaku usaha sudah memasuki ranah pemasaran secara online. Toko offline maupun online dalam memasarkan produknya, UMKM tetap harus memiliki izin usaha atau legal usaha dan ini seringkali diabaikan oleh para pelaku UMKM (Suhardiyah et al., 2020). Bagi para pengusaha yang baru saja memulai usaha, sangat penting untuk memiliki merek usaha dan izin yang terdaftar agar menghindari orang lain menggunakan merek dan izin usaha tersebut (Yohanna, 2016).

Legalitas juga memiliki peran yang sangat penting untuk membantu UMKM dimasa pandemi covid-19. Melalui legalitas yang lengkap, UMKM dapat mengajukan berbagai bantuan yang telah disediakan oleh pemerintah. Adapun bantuan pemerintah dimasa covid ialah dengan menerapkan berbagai program bantuan sosial seperti peningkatan jumlah penerima bantuan pada program keluarga harapan (Pramanik, 2020). Selain bantuan tersebut, terdapat pula program bantuan usaha bagi pengusaha mikro yang menyasar 12 juta usaha dengan nominal bantuan sebesar 2.4 juta.

Akses bantuan pemerintah seperti ini tentu saja hanya berlaku untuk usaha mikro yang memiliki legalitas atau perizinan usaha yang lengkap. Sayangnya banyak sekali usaha mikro, kecil dan menengah yang hanya fokus terhadap hasil penjualan produk mereka dan tidak memperdulikan perizinan usahanya, padahal saat ini untuk membuat izin usaha sangatlah mudah, cepat dan gratis melalui online single submission (OSS). Online single submission 
(OSS) adalah sistem website yang sangat bermanfaat untuk memfasilitasi perizinan dan pengaduan agar nantinya para pengambil keputusan dapat melakukan kegiatan penindakan. Ada banyak hal baru yang disediakan oleh OSS seperti syarat yang seragam melalui automatic approval menu dan yang penting juga, proses OSS sangat cepat karena dokumen tidak melewati proses pengecekan yang lama dan ribet. Selagi dokumen yang diajukan telah sesuai dengan syarat yang diminta oleh sistem, maka izin usaha bisa didapatkan (Arrum, 2019).

Kemudahan akses dalam mendapatkan izin usaha melalui sistem OSS dapat menjadi solusi legalitas bagi UMKM, karena sampai saat ini masih banyak pelaku usaha diIndonesia yang tidak memiliki legalitas usaha. Hal ini salah satunya terjadi akibat ketidaktahuan para pengusaha dalam mengakses izin usaha tersebut (Kusmanto \& Warjio, 2019). Fenomena ini membuktikan bahwa sangat penting bagi pemerintah dan pihak terkait untuk mulai mensosialisasikan serta memfasilitasi para UMKM untuk mengakses, memahami serta mempraktekan pembuatan izin usaha melalui sistem Online single submission (OSS) guna mendorong tumbuhnya UMKM untuk memiliki perizinan legalitas yang nantinya dapat mereka gunakan untuk mengakses berbagai program yang dicanangkan oleh pemerintah.

\section{Metode}

Kegiatan ini dilaksanakan pada hari Rabu tanggal 14 Oktober 2020. Tahap Implementasi/pelaksanaan kegiatan ini terdiri dari beberapa tahap, yaitu :

1. Metode sosialisasi, dilaksanakan dengan melakukan presentasi menggunakan slide power point dihadapan seluruh UMKM peserta pelatihan untuk menjelaskan pengertian Online Single Submission $(O S S)$, apa fungsinya, bagaimana cara mengaksesnya, syarat apa saja yang harus dipersiapkan dan bagaimana langkah-langkah mengisi serta menctak hasil output izin usahanya.

2. Metode diskusi, dilaksanakan dengan melakukan tanya-jawab dengan seluruh UMKM peserta pelatihan tentang sistem Online Single 
Submission (OSS), pertanyaan yang muncul lebih banyak membahas teknis persyaratan yang dibutuhkan, teknis nama yang bisa dicantumkan serta berapa lama izin usaha online ini bisa digunakan.

3. Metode praktek, dilaksanakan dengan melakukan praktek secara langsung dihadapan seluruh UMKM peserta pelatihan tentang bagaimana mengakses dan membuat izin usaha melalui Online Single Submission (OSS) dari awal hingga terbit. Metode ini dilakukan dengan cara mempraktikkan salah satu peserta untuk dibuatkan izin online secara langsung yang dapat dilihat melalui screen proyektor dan peserta lain langsung juga praktek dengan menggunakan smartphone yang mereka miliki.

Metode Sosialisasi, diskusi dan praktek yang dilakukan pemateri selama pelatihan kewirausahaan dengan membuat izin usaha melalui Online Single Submission (OSS) membuat para UMKM peserta pelatihan sangat antusias, bersemangat dan interaktif mengikuti kegiatan hingga acara selesai.

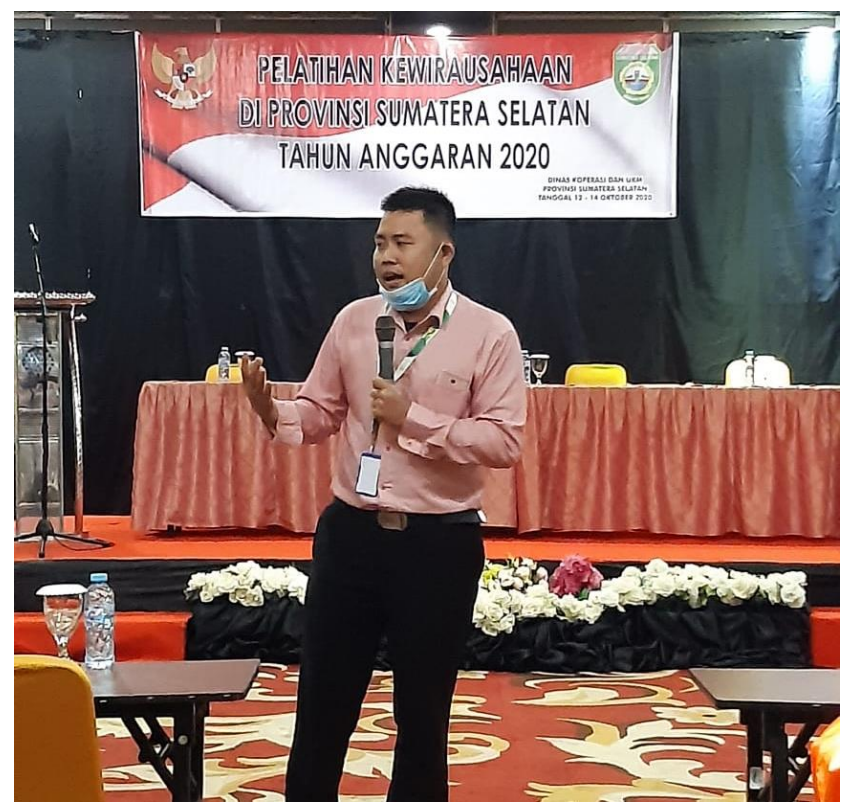

Gambar 1. Pemberian materi kepada peserta UMKM 


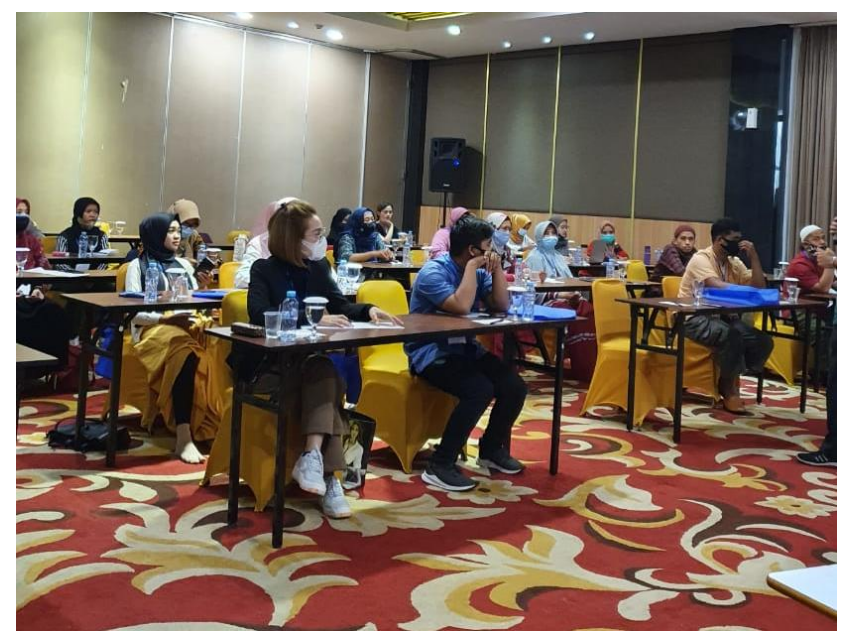

Gambar 2. Peserta pelatihan menyimak materi legalitas usaha

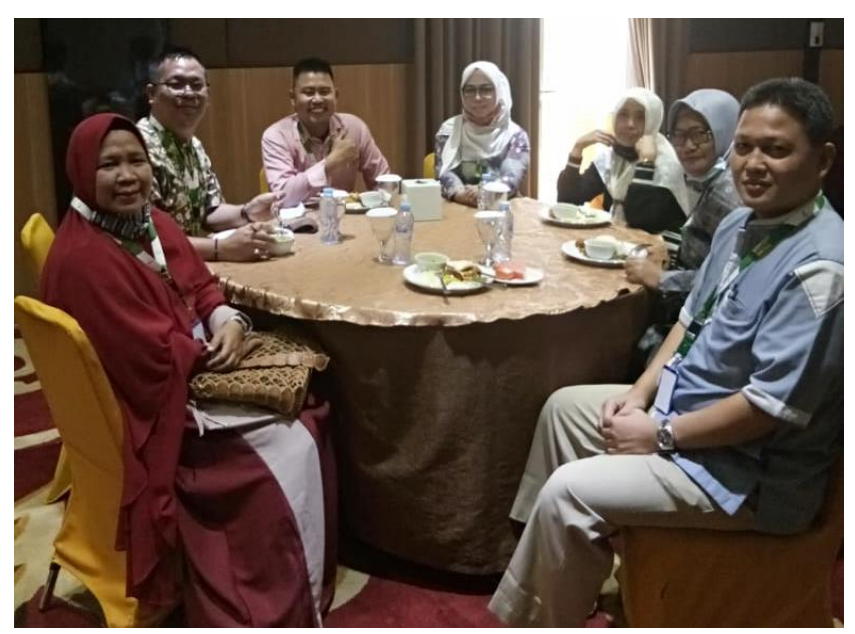

Gambar 3. Diskusi dan konsultasi tentang materi legalitas usaha

\section{Hasil}

Melalui pelatihan kewirausahaan dengan pembuatan izin usaha melalui Online Single Submission (OSS) bagi 30 peserta UMKM di Sumatera Selatan, maka dapat dideskripsikan hasil berikut ini :

1. Proses Persiapan 
Merupakan proses pengumpulan berkas yang nantinya dibutuhkan dalam melakukan pengisian form online, adapun hal yang dibutuhkan ialah NIK KTP, Nomor NPWP pribadi, nomor handphone aktif serta email aktif.

2. Proses Kelengkapan Syarat

Merupakan proses melengkapi berkas yang belum dimiliki oleh peserta pelatihan. Ternyata selama proses pelatihan ditemukan bahwa belum semua UMKM memiliki nomor NPWP pribadi dan email aktif. Untuk yang belum memiliki email dibantu untuk dibuatkan saat itu juga, namun untuk yang belum memiliki NPWP maka segera didaftarkan secara online. Secara tidak langsung dalam pelatihan ini, pemateri memberikan penyuluhan tambahan akan pentingnya peran NPWP pribadi dan email aktif bagi peserta.

3. Proses Pengisian Form Online

Merupakan proses penginputan seluruh berkas yang sudah disiapkan untuk kemudian diisi ke dalam form online yang sudah disediakan melalui sistem Online Single Submission (OSS). Proses ini normalnya hanya membutuhkan waktu 10 menit saja, namun dikarenakan proses penginputan data online ini dipraktekan di depan seluruh peserta melalui infocus screen dan dijelaskan secara perlahan-lahan, maka waktu yang dihabiskan adalah 45 menit. Proses penginputan data oleh peserta terkendala tampilan screen yang berbeda, dimana pemateri menggunakan tampilan desktop laptop, sedangkan peserta menggunakan screen smartphone, namun demikian dengan penjelasan sederhana, peserta pelatihan pada akhirnya tetap bisa mengisi form online ini secara mandiri melalui smartphone mereka masing-masing.

4. Proses Penerbitan Izin Usaha

Merupakan proses pengunduhan berkas izin yang telah diterbitkan dari sistem Online Single Submission (OSS). Setelah izin diunduh dan ditampilkan di depan seluruh peserta, mereka sangat bersemangat dan sangat antusias karena mereka jadi jauh lebih percaya bahwa membuat 
perizinan itu ternyata mudah, cepat dan gratis. Hal ini ternyata mampu merubah mindset para UMKM peserta pelatihan yang menganggap bahwa proses izin usaha selalu memakan waktu, tenaga dan biaya.

5. Hasil Akhir Pencapaian

Capaian akhir dari pelaksanaan kegiatan Pengabdian Kepada Masyarakat (PKM) yang telah dilaksanakan dapat identifikasi melalui kuisioner yang disebar sebelum dan sesudah kegiatan pelatihan. Berdasarkan hasil kuisioner yang telah disebar sebelum kegiatan dilaksanakan, didapatkan data bahwa terdapat 26,67\% UMKM peserta kegiatan telah memiliki izin legalitas usaha, namun mayoritas UMKM atau sebesar $63,33 \%$ belum memiliki legalitas usaha dan terdapat $10 \%$ UMKM yang menjawab tidak tahu atau belum mengerti tentang izin legalitas usaha. Setelah mengikuti rangkaian kegiatan pembuatan izin usaha melalui Online Single Submission (OSS), serta dilakukan penyebaran kuisioner setelah pelatihan, didapatkan data bahwa seluruh peserta kegiatan (100\%) telah memiliki memiliki izin legalitas usaha. Berdasarkan capaian tersebut, maka terlihat bahwa pelatihan kewirausahaan ini telah berhasil memberikan pemahaman tentang cara pembuatan legalitas usaha secara online bagi seluruh peserta pelatihan.

Setelah selesai mengikuti kegiatan ini, seluruh peserta UMKM direkomendasikan untuk menyebarkan ilmu yang didapat dari hasil pelatihan ini kepada para UMKM yang ada di sekitar mereka yang belum berkesempatan ikut dalam pelatihan pembuatan izin online ini. Diharapkan dengan peran partisipasi aktif UMKM dalam menyebarkan informasi, akan mendorong banyak pelaku UMKM lainnya yang belum memiliki izin, untuk kemudian termotivasi membuat izin usaha secara online melalui sistem Online Single Submission (OSS).

\section{Diskusi}

Hadirnya usaha kecil dan menengah (UMKM) menjadi hal yang sangat baik dan berkontribusi signifikan terhadap ekonomi di daerah, sejarah telah membuktikan bahwa usaha kecil dan menengah merupakan keunggulan ekonomi yang mampu berkontribusi terhadap perekonomian di Indonesia 
(Febriyantoro et al., 2019). Namun demikian, saat ini UMKM masih menghadapi banyak kendala sehubungan dengan kegiatan usaha yang mereka jalankan, seperti : (a) proses izin usaha yang bertele-tele, tingginya biaya transaksi dan munculnya banyak pungutan; selanjutnya (b) UMKM juga mengalami kendala dari kegiatan usaha yang dijalankan dengan tidak sehat. Sebagai tambahan, terobosan pemerintah yang menerapkan sistem otonomi di daerah demi mendukung suasana usaha yang baik bagi UMKM ternyata beum memberikan hasil yang merata (Putri, 2017).

Permasalahan UMKM terutama tentang legalitas perizinan membutuhkan pembinaan agar mereka lebih memahami proses membuat legalitas sehingga nantinya membuat konsumen lebih percaya terhadap produk yang dijual oleh UMKM (Kartikasari, 2019). Melalui pembinaan dengan cara pemberian pelatihan pembuatan izin usaha secara online melalui sistem Online Single Submission (OSS), diharapkan agar UMKM di Sumatera Selatan lebih terbuka cara berpikirnya bahwa saat ini izin usaha adalah suatu hal yang sangat mudah, cepat dan gratis untuk didapat sehingga tidak menjadi kendala. Peran pembinaan pemerintah terhadap UMKM memang sangat dibutuhkan, mengingat UMKM banyak dikelolah oleh masyakat yang masih awam terhadap berbagai informasi tentang berbagai hal untuk memajukan UMKM, dan yang memiliki kompetensi di dalam bidang pengelolaan untuk kemajuan UMKM adalah pemerintah (Nirwana et al., 2017)

\section{Kesimpulan}

Kegiatan pelatihan ini berhasil memberikan pemahaman tentang cara pembuatan legalitas usaha secara online bagi seluruh UMKM peserta pelatihan. Mayoritas UMKM yang awalnya tidak memiliki dan tidak paham tentang legalitas usaha ternyata bisa diarahkan untuk memiliki izin usaha dengan cara mengakses sistem online single submission (OSS). Hasil dari pelatihan ini membuktikan bahwa pembuatan legalitas usaha bukanlah suatu hal yang sulit dan dapat dilakukan oleh setiap UMKM. 


\section{Pengakuan/Acknowledgements}

Terima kasih kepada pihak Dinas Koperasi dan UMKM Provinsi Sumatera Selatan dan para peserta UMKM Sumatera Selatan yang telah memberikan kesempatan dan meluangkan waktu dalam pelaksanaan kegiatan pelatihan kewirausahaan mengenai pembuatan izin usaha melalui sistem online single submission (OSS) bagi UMKM di Sumatera Selatan.

\section{Daftar Referensi}

Arrum, D. A. (2019). Kepastian Hukum Dalam Perizinan Berusaha Terintegrasi Secara Elektronik (Online Single Submission) di Indonesia. Jurist-Diction, 2(5), 1631-1654.

Febriyantoro, M. T., Harris, I., Sundiman, D., Pradana, M. R., \& Lestari, E. (2019). Pelatihan Kewirausahaan dan Peningkatan Kualitas Manajemen dan Tata Kelola Keuangan Bagi Pelaku UMKM di Lingkungan PKK Tiban Global Batam. Jurnal Abdimas BSI: Jurnal Pengabdian Kepada Masyarakat, 2(2), 271-279. https://doi.org/10.31294/jabdimas.v2i2. 5981

Kartikasari, M. D. (2019). Penguatan Umkm Melalui Kualitas Dan Legalitas Pengusaha Makanan Kota Tegal. Diklat Review: Jurnal Manajemen

Pendidikan Dan Pelatihan. 3(2), 152-155.https://doi.org/10.35446 /diklatreview.v3i2.389

Kusmanto, H., \& Warjio, W. (2019). Pentingnya Legalitas Usaha bagi Usaha Mikro Kecil dan Menengah. JUPIIS: JURNAL PENDIDIKAN ILMUILMU SOSIAL, 4(2), 103-108.https://doi.org/10.24114/jupiis.v11i2. 13583

Nirwana, D. C., Muhammadiah, M., \& Hasanuddin, M. (2017). Peran

Pemerintah Dalam Pembinaan Usaha Kecil Menengah Di Kabupaten Enrekang. KOLABORASI : JURNAL ADMINISTRASI PUBLIK, 3(1), 114. https://doi.org/10.26618/kjap.v3i1.890

Pramanik, N. D. (2020). Dampak bantuan paket sembako dan bantuan langsung tunai terhadap kelangsungan hidup masyarakat padalarang pada masa pandemi covid 19. Jurnal Ekonomi, Sosial Dan Humaniora, 1(12), 113-120.

Putri E, H. (2017). Efektivitas Pelaksanaan Program Pengembangan Usaha Mikro Kecil Dan Pada Dinas Koperasi Dan Umkm Kota Samarinda ). EJournal Administrasi Negara, 5(1), 5432-5445.

Suhardiyah, M., et al. (2020). Legalisasi Dan Pengelolaan Usaha Pada 
UMKM. Ekobis Abdimas : Jurnal Pengabdian Masyarakat, 1(1), 45-53. https://doi.org/10.36456/ekobisabdimas.1.1.45-53.2340

Thaha, A. F. (2020). Dampak Covid-19 Terhadap UMKM di Indonesia. Jurnal Brand, 2(1), 123-130.

Yohanna, L. (2016). Upaya Peningkatan Usaha Masyarakat Melalui Pengurusan Perizinan Usaha dan Merek. Jurnal Surya : Seri Pengabdian Kepada Masyarakat, 2(1), 73-78. 